bamento. Existiram diferenças, estatisticamente significativas, entre o mesmo número de classificações atribuídas pelos dois avaliadores em cada grupo. Rejeitou-se a hipótese nula $(\mathrm{k}=0)$ para um valor $\alpha<0,05$ para as 3 variáveis. Existiu uma concordância fraca entre os dois avaliadores.

Conclusões: Os erros mais frequentes surgiram, no grupo de dentes posterior, preparado em mão pelos estudantes da FMDUP. Quer em dentes pré-molares preparados em mão, quer em Fantoma ${ }^{\circledR}$, para coroa cerâmica pura, o erro mais presente residiu no desgaste oclusal insuficiente. Os erros menos comummente encontrados nas preparações dentárias do setor posterior foram na redução axial e na posição cervical da linha de acabamento. A concordância fraca entre os dois avaliadores, pode ser explicada pelo diferente grau de experiência do Professor de Prótese Fixa e do estudante da FMDUP. http://doi.org/10.24873/j.rpemd.2018.11.362

\section{\#129 Efeito de bebidas desportivas e branqueamento dentário na microdureza do esmalte}

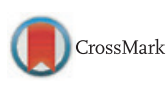

Filipe José Gabriel Silva*, Ana Filipa Chasqueira, João Carlos Ramos, Jaime Portugal

Faculdade de Medicina da Universidade de Coimbra; Faculdade de Medicina Dentária da Universidade de Lisboa

Objetivos: Avaliar in vitro o efeito de quatro bebidas desportivas e da sua conjugação com branqueamento dentário na microdureza do esmalte dentário.

Materiais e métodos: A partir de 25 dentes humanos foram obtidos 50 espécimes com superfície em esmalte. Os espécimes foram distribuídos aleatoriamente por 10 grupos experimentais $(n=5)$ de acordo com as várias combinações possíveis entre bebida desportiva (controlo sem bebida; Isostar; Isocarb; $100 \%$ Whey Protein; Ultra Recovery) e o branqueamento dentário (controlo sem branqueamento; branqueamento com peróxido de carbamida 16\%). Os espécimes de cada grupo foram sujeitos a 14 ciclos de imersão na respetiva bebida durante 60 minutos (1 ciclo por dia) intercalados com imersão em saliva. A aplicação do agente branqueador foi realizada após cada um dos ciclos de imersão, durante 4 horas. Os testes de microdureza Vickers (HV) foram realizados com um microdurometro (100gF; 10 segundos) em 3 momentos (medição inicial antes dos ciclos de exposição à bebida/branqueamento (T0); imediatamente após o término dos 14 ciclos de imersão (T1); e 24 horas após o término dos 14 ciclos de imersão (T2)). Os dados de HV foram analisados estatisticamente, testes não paramétricos de Friedman, Mann-Whitney e Kruskal-Wallis (alfa=0,05).

Resultados: Os valores de HV sofreram uma diminuição estatisticamente significativa de T0 para $\mathrm{T} 1(\mathrm{p}<0,001)$, mantendo-se sem alterações significativas de T1 para T2 $(p=0,001)$. A HV foi influenciada de forma estatisticamente significativa $(p<0,001)$ pela imersão em bebida desportiva, tanto em T0 como em T1. A imersão as bebidas isotónicas, Isostar e Isocarb, conduziu a uma diminuição $(p<0,05)$ de HV, relativamente ao grupo de controlo. Os resultados obtidos após imersão nos suplementos proteicos, $100 \%$ Whey Protein e Ultra Recovery, foram estatisticamente $(p>0,05)$ semelhantes aos obtidos no grupo controlo. A exposição ao peróxido de carbamida $16 \%$ não influenciou os valores de HV, nem em T1 $(p=0,635)$ em em T2 $(p=0,915)$.

Conclusões: A exposição às bebidas isotónicas teve um impacto negativo na microdureza do esmalte. No entanto, a microdureza do esmalte não foi afetada pela exposição aos suplementos proteicos. O branqueamento dentário não teve impacto na microdureza do esmalte. http://doi.org/10.24873/j.rpemd.2018.11.363

\#130 Atitudes e comportamentos de saúde oral da população chinesa adulta residente em Portugal

Shuangshuang Wu*, Sónia Mendes, Mário Bernardo

FMDUL

Objetivos: Os indivíduos de origem chinesa constituem a quinta maior comunidade imigrante em Portugal. Estes indivíduos têm antecedentes sociais e culturais diferentes dos portugueses, assim considerou-se interessante recolher dados epidemiológicos sobre a saúde oral desta comunidade. Os objetivos deste estudo foram: a) Caracterizar esta população relativamente a comportamentos e atitudes relacionados com a saúde oral; b) Relacionar os comportamentos e atitudes com a idade, sexo, nível de instrução e número de anos de residência em Portugal.

Materiais e métodos: Foi realizado um estudo observacional e transversal. A recolha de dados foi realizada entre novembro de 2017 e fevereiro de 2018, através de um questionário. A divulgação do questionário foi realizada on-line (rede WeChat) e em papel (locais frequentados pela comunidade chinesa). Foi efetuada a estatística descritiva dos dados e utilizado o teste do qui-quadrado $(\alpha=0,05)$.

Resultados: A amostra foi constituída por 218 indivíduos. A escovagem bidiária e o uso diário de fio dentário foram reportados por $75,2 \%$ e $11,1 \%$ dos participantes, respetivamente. Cerca de metade $(47,9 \%)$ dos participantes referiu não ter visitado o dentista nos últimos 12 meses, sendo a língua $(11,9 \%)$ e a falta de confiança nos dentistas locais $(5,6 \%)$ barreiras referidas para a não realização. A maioria (85,3\%) tinha mais de 20 dentes presentes na cavidade oral, 7\% usava prótese removível e 8,7\% aparelho ortodôntico. Quase metade (46,3\%) dos participantes referiu a China como local preferencial para realizar tratamentos dentários. Os participantes que residiam há mais tempo em Portugal referiram menor preferência para ir tratar os dentes à China. Os indivíduos mais velhos tinham menos dentes e apresentavam menor satisfação com o estado de saúde dos dentes. As mulheres referiram escovar os dentes com mais frequência e mais hipersensibilidade dentária. Os participantes com maior nível de instrução referiram maior frequência de tratamento ortodôntico, maior satisfação com o estado dos dentes, maior frequência de visitas ao dentista e maior frequência de destartarizações.

Conclusões: Apesar das limitações da amostra, este estudo permitiu obter informações sobre a comunidade chinesa adulta, residente em Portugal. Este conhecimento é importante para a criação e implementação de medidas de promoção da saúde oral, adaptadas às necessidades e características socioculturais desta população.

http://doi.org/10.24873/j.rpemd.2018.11.364 